\title{
Yersinia associated arthritis in SHR rats: effect of the microbial status of the host
}

\author{
Christel Gripenberg-Lerche, Paavo Toivanen
}

\begin{abstract}
Following the intravenous injection of live Yersinia enterocolitica 0:8, 50-69\% of SHR rats developed arthritis; these rats were antibody free against all rat pathogens tested. In contrast, only $20-25 \%$ of SHR rats which had serum antibodies against Bacillus piliformis, Kilham rat virus, and Toolan $H-1$ virus developed arthritis. The results indicate that the microbial load of the host has a profound effect on the susceptibility to experimental arthritis.
\end{abstract}

(Ann Rheum Dis 1993; 52: 223-228)

Intravenous injection of live Yersinia enterocolitica $\mathrm{O}: 8$ into SHR or Lewis rats results within 10-14 days in the development of inflammatory arthritis resembling human reactive arthritis. The arthritis is preceded by weight loss, ruffling of the fur, and tenderness of the legs on movement, followed by erythema and gradually worsening swelling and impaired movement of the joints. The arthritis is most common in the ankle joints, with marked swelling around the Achilles tendon, and usually affects one to three limbs. In most of the animals arthritis subsides within four weeks. ${ }^{1-3}$ Following our long term experiments with SHR rats, ${ }^{3}$ we became puzzled by the different susceptibility to arthritis of rats supplied by two different producers, even though the animals were of the same genetic background and with the same level of hypertension. Therefore, experiments have been conducted to induce yersinia associated arthritis using different external environments, and at the same time to study the microbiological status of the animals. The results obtained indicate that the microbial load of the rats has an effect on susceptibility to experimentally induced arthritis.

\section{Materials and methods}

RATS

Department of Medical Microbiology, Turku University, Kiinamyllynkatu 13, SF-20520 Turku, Finland C Gripenberg-Lerche $P$ Toivanen

Correspondence to: Christel Gripenberg-Lerche Accepted for publication 30 October 1992
Adult male SHR rats weighing 225-275 g were purchased from Möllegaard Ltd, Skensved, Denmark, and from Charles River Laboratories, Kingston, NY, USA. These rats are characterised by spontaneous hypertension with an average blood pressure no lower than 184(17) mmHg. ${ }^{4}$ The SHR rats from Möllegaard have their origin in Kyoto School of Medicine (Dr Okamoto), Japan, and arrived in Möllegaard breeding centre via the National
Institutes of Health, USA in 1977 (F 39). At the time when our experiments started the rats were in the inbred generations F 59-61. The Charles River's colony was first obtained from the National Institutes of Health in 1973; during our experiments it was in generations 83-86. The following allelic profile is common for the two SHR strains used by us: $\mathrm{Hbb}^{\mathrm{a}}$, Pep$3^{\mathrm{a}}$, Es- $^{\mathrm{a}}, \mathrm{Es}-2^{\mathrm{a}}, \mathrm{Es}-6^{\mathrm{a}}, \mathrm{Es}-8^{\mathrm{b}}, \mathrm{Es}-10^{\mathrm{a}}, \mathrm{Mup}-1^{\mathrm{a}}$, $\mathrm{RT} 1^{\mathrm{k}}, \mathrm{RT} 2^{\mathrm{b}}$, and RT ${ }^{\mathrm{a}}$. They were found to be dissimilar only for the blood group alloantigen RT3, with RT $3^{b}$ for Möllegaard SHR rats and RT3 $^{a}$ for those from Charles River. The rats were kept in Macrolon III cages, three to four animals in each, on autoclaved aspen wood bedding material. They were conventionally maintained on a standard diet and given tapwater ad libitum; for the experiments in environment III food and water were autoclaved. According to the health monitoring reports by the suppliers, the rats could be divided into two categories as follows (all rats in one category were from one supplier).

\section{Status $A$}

No serum antibodies to the following rat pathogens: Hantaan virus, Leptospira spp, Mycoplasma pulmonis, pneumonia virus of mice (PVM), Reo virus type 3 (Reo 3), Sendai virus and Sialodacryoadenitis virus (SDAV). The animals were antibody positive for Bacillus piliformis, Kilham rat virus (KRV), and Toolan $\mathrm{H}-1$ virus. Bacterial cultures were negative for Corynebacterium kutscheri, $M$ arthritidis, $M$ pulmonis, Pasteurella pneumotropica, Pseudomonas aeruginosa, Salmonella spp, Spirillum minus, and Streptococcus pneumoniae.

\section{Status $B$}

No serum antibodies to Hantaan virus, KRV, lymphocytic choriomeningitis virus (LCMV), PVM, Reo 3, SDAV, Sendai virus, and Toolan $\mathrm{H}-1$ virus. Bacterial cultures were negative for Bordetella bronchiseptica, $C$ kutscheri, $M$ pulmonis, Salmonella spp, and Streptobacillus moniliformis. There was no notation regarding $B$ piliformis.

\section{ENVIRONMENT}

Experiments were carried out in three different environments characterised as follows:

Environment $I$ is the temperature and humidity controlled animal quarters of our department. A common air duct system 
supplies ventilation to all rooms in the facility housing mice, rats, guinea pigs, rabbits, and chickens.

Environment II is an old wooden army barrack, located approximately $1.5 \mathrm{~km}$ from environment I. It was not temperature and humidity controlled. A room fan was used during the day to prevent overheating. This building had never previously housed laboratory animals. To eliminate microbial contamination only status B rats were allowed in this environment. Our short term use of this facility was terminated because of remodelling.

Environment III is the same as environment I, which was thoroughly cleaned and sterilised. Only status B rats were allowed. The air pressure in the rooms housing the rats was increased to prevent admixture with air in other parts of the facility.

In all environments lighting was controlled with a 12 hours on and 12 hours off cycle. Experiments with rats of status A were conducted in environment I and those with rats of status B in environments I, II, and III.

\section{BACTERIA}

Yersinia enterocolitica O:8 WA strain, obtained originally from Dr P Gemski, was used. The strain is virulence plasmid positive and autoagglutination positive. ${ }^{5}$ The bacteria were stored at $-70^{\circ} \mathrm{C}$ in tryptone soy broth (TSB) (Oxoid, Basingstoke, Hampshire, UK) containing $20 \%$ glycerol. Before each experiment the bacteria were recovered by culturing at room temperature on tryptic soy agar (TSA) plates. Plasmid positive colonies were selected by colony appearance on agar plates and by autoagglutination. Further cultures were carried out in tryptic soy broth at room temperature. After culturing, the bacteria were washed with $0.9 \% \mathrm{NaCl}$. The bacterial dose was adjusted using $\mathrm{McF}$ arland turbidity standards. The concentration of viable bacterial cells was further estimated by the most probable number method ${ }^{6}$ or using colony counts on TSA agar plates. The rats were given a single dose $\left(10^{4}, 10^{5}\right.$, or $\left.10^{6}\right)$ of live $Y$ enterocolitica $0: 8$ into a tail vein.

\section{ESTIMATION OF ARTHRITIS}

Each limb was examined every second day by two independent observers. A score from 0 to 4 was assigned for each limb, 0 representing negative and 4 gross distortion with severe arthritic changes. The rats were monitored for 30 days after the bacterial inoculation.

BACTERIAL CULTURES

After the rats were killed, tissue samples were taken from the ankle joints, livers, spleens, inguinal lymph nodes, and Peyer's patches using sterile techniques. Blood and faeces were also cultured for yersinia. The samples were cultured by direct plating on TSA agar and after enrichment for one and three weeks at $4^{\circ} \mathrm{C}$ in TSB. Yersinia enterocolitica $\mathrm{O}: 8$ colonies were identified with API-20E strips (API System SA, Montalieu, France).

SEROLOGICAL TESTING FOR YERSINIA ENTEROCOLITICA SPECIFIC ANTIBODIES For the detection of yersinia specific antibodies, a modification of the previously published enzyme linked immunosorbent assay (ELISA) was used. $^{7}$ Formalin killed and sodium dodecyl sulphate treated bacteria were used as the antigen. The bacterial suspension was diluted in phosphate buffered saline (PBS), pH 7.3, to contain $0.5 \mu \mathrm{g}$ protein $/ \mathrm{ml}$. The antigen was absorbed into polystyrene microtitre plates (Dynatec, UK) by overnight incubation at $+37^{\circ} \mathrm{C}$. The plates were then washed three times with $0.9 \% \mathrm{NaCl}$ solution containing $0.5 \%$ Tween (NaCl-Tween) and unspecific binding was blocked with $1 \%$ normal sheep serum (NSS) in PBS at $37^{\circ} \mathrm{C}$ for two hours. After washing, $75 \mu \mathrm{l}$ volumes of rat serum, diluted 1:500 in 1\% NSS-PBS, were added to the plates and incubated at $37^{\circ} \mathrm{C}$ for two hours. The plates were washed again and antirat immunoglobulin (anti- $\gamma$, anti- $\alpha$, or anti- $\mu$ ) was added on separate plates. For IgG class, alkaline phosphatase conjugated sheep antirat $\gamma$ (The Binding Site, Birmingham Research Park, Birmingham, UK) was used. For IgA and IgM class determinations, unconjugated monoclonal murine IgGl antirat $\alpha$ and antirat $\mu$ (Janssen Biochimica, Beerse, Belgium) were applied; as a second antibody alkaline phosphatase conjugated goat antimouse IgG+IgM was used. After overnight incubation at room temperature the plates were washed. Thereafter $75 \mu \mathrm{l}$ of $1 \mathrm{mg}$ 1-p-nitrophenylphosphate (Sigma Chemical, St Louis, MO, USA) per millilitre diethanolamine- $\mathrm{MgCl}_{2}$-buffer ( $\mathrm{pH} 10$, Orion Diagnostica, Helsinki, Finland) was added to each well and the plates were incubated for 20 minutes at $37^{\circ} \mathrm{C}$ (30 minutes for IgG class antibodies). To stop the reaction, $125 \mu$ l of 1 $\mathrm{M} \mathrm{NaOH}$ was added to each well. The optical absorbance was measured with a Multiscan photometer (Finnpipette Analyzer System, Finnpipette-Labsystems, Helsinki, Finland) at a wavelength of $405 \mathrm{~nm}$. The blood samples were randomised so that samples from injected and non-injected rats were present on the same microtitre plate.

SEROLOGICAL TESTING FOR OTHER ANTIBODIES At the end of the experiments selected rat serum samples were tested for antibodies against $B$ piliformis, $\mathrm{KRV}, M$ pulmonis, and Toolan $\mathrm{H}-1$ virus by ELISA, indirect immunofluorescence, or haemagglutination inhibition. The tests were carried out by the Central Institute for Laboratory Animal Breeding, Hannover, Germany, and The Microbiology Laboratories, Middlesex, UK.

MEASUREMENT OF GAMMAGLOBULIN LEVELS The samples used were taken before the rats were injected with yersinia. Serum gamma- 
Table 1 Incidence of yersinia associated arthritis in SHR rats housed in different environments. Three different bacterial doses were used

\begin{tabular}{|c|c|c|c|c|c|c|c|c|c|}
\hline \multirow[b]{3}{*}{$\begin{array}{l}\text { Rat } \\
\text { status }\end{array}$} & \multirow[b]{3}{*}{ Environment } & \multicolumn{6}{|c|}{ No of bacteria injected into each rat } & \multicolumn{2}{|l|}{ Total No (\%) } \\
\hline & & \multicolumn{2}{|l|}{$10^{4}$} & \multicolumn{2}{|l|}{$10^{5}$} & \multicolumn{2}{|l|}{$10^{6}$} & \multirow[b]{2}{*}{$\begin{array}{l}\text { Incidence of } \\
\text { arthritis }\end{array}$} & \multirow[b]{2}{*}{$\begin{array}{l}\text { No of } \\
\text { deaths }\end{array}$} \\
\hline & & $\begin{array}{l}\text { Incidence of } \\
\text { arthritis }\end{array}$ & $\begin{array}{l}\text { No of } \\
\text { deaths }\end{array}$ & $\begin{array}{l}\text { Incidence of } \\
\text { arthritis }\end{array}$ & $\begin{array}{l}\text { No of } \\
\text { deaths }\end{array}$ & $\begin{array}{l}\text { Incidence of } \\
\text { arthritis }\end{array}$ & $\begin{array}{l}\text { No of } \\
\text { deaths }\end{array}$ & & \\
\hline $\begin{array}{l}\text { A } \\
\text { A } \\
\text { B } \\
\text { B } \\
\text { B }\end{array}$ & $\begin{array}{l}\text { I } \\
\text { I } \\
\text { I } \\
\text { IIg } \\
\text { III }\end{array}$ & $\begin{array}{l}3 / 24^{\star} \\
0 / 3 \\
3 / 3 \\
5 / 7 \\
4 / 7\end{array}$ & $\begin{array}{l}2 / 26 \dagger \\
0 / 3 \\
0 / 3 \\
0 / 7 \\
1 / 8\end{array}$ & $\begin{array}{l}5 / 24 \\
1 / 4 \\
3 / 6 \\
5 / 7 \\
5 / 12\end{array}$ & $\begin{array}{l}4 / 28 \\
0 / 4 \\
0 / 6 \\
2 / 9 \\
2 / 14\end{array}$ & $\begin{array}{l}8 / 16 \\
1 / 3 \\
2 / 3 \\
1 / 2 \\
5 / 9\end{array}$ & $\begin{array}{l}17 / 33 \\
0 / 3 \\
6 / 9 \\
9 / 11 \\
4 / 13\end{array}$ & $\begin{array}{r}16 / 64(25) \\
2 / 10(20) \\
8 / 12(67) \\
11 / 16(69) \\
14 / 28(50)\end{array}$ & $\begin{array}{c}23 / 87(26) \\
0 / 10(0) \\
6 / 18(33) \\
11 / 27(41) \\
7 / 35(20)\end{array}$ \\
\hline
\end{tabular}

*No of rats with arthritis/total No of survivors.

†No of deaths/total No of rats.

†Filter tops on all cages after bacterial injection.

$\oint$ Filter tops on all cages throughout the experiment.

globulin levels were determined by agarose gel electrophoresis ${ }^{8}$ at the department of clinical chemistry, Swedish University of Agricultural Sciences, Uppsala, Sweden.

\section{Results}

In the initial experiments of this study conducted with status A rats in environment I, the incidence of arthritis was $3 / 24,5 / 24$, and $8 / 16$ with bacterial doses of $10^{4}, 10^{5}$, and $10^{6}$, respectively, given intravenously (table 1 ). Altogether 87 rats were used in these experiments with a total mortality of $26 \%$ and a total incidence of arthritis of $25 \%$. The incidence of arthritis also remained about the same $(2 / 10)$ in a subsequent small experiment with the same kind of rats in the same environment, with the only difference that the animals were protected by filter tops on the cages after the bacterial inoculation (table 1). This incidence of arthritis is considerably less than that in our previously published series, where arthritis was observed in 23 of 48 SHR rats $(48 \%){ }^{3}$

As the next step, experiments were conducted with status B rats, first under exactly the same conditions as for status A rats, and thereafter in two other external environments (environments II and III; table 1). In these experiments the incidence of arthritis was $50-69 \%$, being $67 \%$ under the same external conditions where status A rats developed arthritis only in $20 \%$ (table 1 ). The death rate of status $B$ rats in the experiments conducted in the three different environments varied from 20 to $41 \%$, about the same as that

Table 2 Maximum arthritic score observed in different environments. Mean(SD) arthritic scores were calculated from the maximum score observed for each arthritic animal during the experiment. No significant statistical differences were seen between the $A$ and $B$ groups

\begin{tabular}{|c|c|c|c|c|c|}
\hline \multirow[b]{2}{*}{$\begin{array}{l}\text { Rat } \\
\text { status }\end{array}$} & \multirow[b]{2}{*}{ Environment } & \multicolumn{3}{|c|}{ No of bacteria injected into each rat } & \multirow[b]{2}{*}{ Total } \\
\hline & & $10^{4}$ & $10^{5}$ & $10^{6}$ & \\
\hline A & I & $\begin{array}{l}6.8(2.0) \\
(n=3)\end{array}$ & $\begin{array}{l}5.6(3.4) \\
(n=5)\end{array}$ & $\begin{array}{c}4.8(2.6) \\
(n=8)\end{array}$ & $\begin{array}{l}5.4(2.7) \\
(n=16)\end{array}$ \\
\hline A & $I^{\star}$ & & $2.5 t$ & $10+$ & \\
\hline B & $I^{\star}$ & $\begin{array}{l}6.3(3.5) \\
(n=3)\end{array}$ & $\begin{array}{l}5.2(2.4) \\
(n=3)\end{array}$ & $2.5,7 \dagger$ & $\begin{array}{l}5.5(2.7) \\
(\mathrm{n}=8)\end{array}$ \\
\hline B & II $\ddagger$ & $\begin{array}{l}5.5(2.9) \\
(n=5)\end{array}$ & $\begin{array}{l}7.6(3.8) \\
(n=5)\end{array}$ & $8+$ & $\begin{array}{l}6.7(3.2) \\
(n=11)\end{array}$ \\
\hline B & III & $\begin{array}{l}3.4(2.0) \\
(n=4)\end{array}$ & $\begin{array}{l}6.1(2.8) \\
(n=5)\end{array}$ & $\begin{array}{c}3.1(1.4) \\
(n=5)\end{array}$ & $\begin{array}{l}4.3(2.5) \\
(n=14)\end{array}$ \\
\hline
\end{tabular}

^Filter tops on all cages after bacterial injection.

$\dagger$ Individual values are given.
$\ddagger$ Filter tops on all cages throughout the experiment. observed with the status $A$ rats in environment I $(23 / 97 ; 24 \%)$.

In spite of the difference between status $A$ and status $B$ rats in the incidence of arthritis, no clear difference was observed in the severity of the arthritis (table 2). Only the development of arthritis was slightly slower in the status A rats than in the status $B$ rats (table 3 ); on average, the onset of arthritis occurred in status A rats 18.0(3.6) (mean(SD)) days after the bacterial inoculation, whereas in status B rats the corresponding figure was $13.4(4.9)$ days ( $\mathrm{p}=0.0011$ by Student's $t$ test). The recovery of $Y$ enterocolitica $0: 8$ at the end of the experiment from the different organs was about the same in status A and status B rats (table 4). No live bacteria were isolated from the ankle joints of eight status A rats studied, however, whereas four of 33 status B rats gave a positive joint culture.

Development of yersinia specific antibodies was studied in serum samples taken 14 and 30 days after the bacterial inoculation. IgM, IgA, and IgG class antibodies were determined separately (figure). After bacterial inoculation no significant differences were observed between status A and status B rats. Antibody levels generally tended to be higher in the animals developing arthritis than in those without arthritis. A remarkable difference was noted at the beginning of the experiments in the background values for yersinia specific antibodies, particularly for those of IgG class. For the status A rats they were significantly higher than for status $B$ rats in environments I, II, or III $(p<0.001,0.02$, and 0.0001 ,

Table 3 Onset of arthritis after intravenous Yersinia enterocolitia O:8 injection. Mean(SD) values (days) are given. Only arthritic animals are included

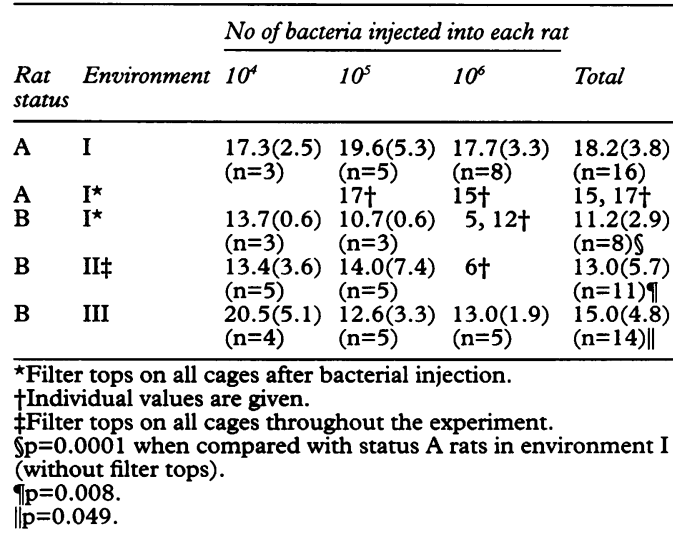



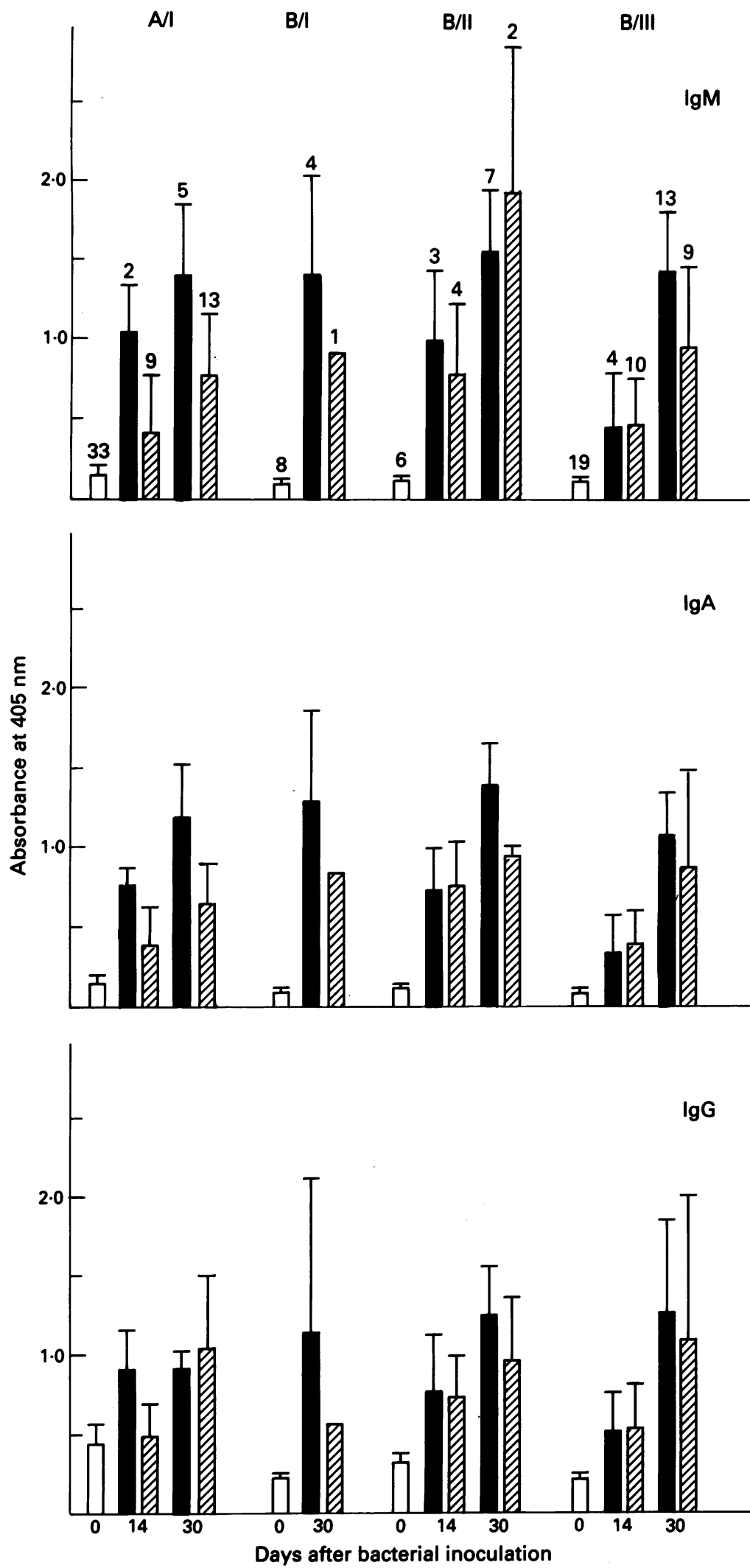

Serum levels of Yersinia enterocolitica $0: 8$ specific antibodies in uninjected rats (white columns), in rats developing arthritis (black columns), and in rats which did not develop arthritis (hatched columns) after bacterial inoculation. Serum samples were taken 14 and 30 days after intravenous injection of live $\mathrm{Y}$ enterocolitica $0: 8$. For different experiments see tables. Number above the columns refers to number of rats. Mean values $+S D$ are given.
Table 4 Recovery of Yersinia enterocolitica O:8 at the end of experiment. See tables 1-3 for different experiments. Summarised results for bacterial doses of $10^{4}, 10^{5}$, and $10^{6}$ are presented. Arthritic and non-arthritic rats were randomly chosen for bacterial culture

\begin{tabular}{llllr}
\hline \multirow{5}{*}{ Organ } & \multicolumn{5}{l}{ Rat status/environment } \\
\cline { 2 - 5 } & $A / I$ & $B / I$ & $B / I I$ & $B / I I I$ \\
\hline Joint & $0 / 8^{\star}$ & $2 / 8$ & $1 / 2$ & $1 / 21$ \\
Blood & $1 / 5$ & $2 / 3$ & $0 / 3$ & $1 / 21$ \\
Liver & $3 / 8$ & $5 / 8$ & $1 / 3$ & $11 / 22$ \\
Spleen & $2 / 8$ & $4 / 8$ & $3 / 3$ & $15 / 22$ \\
Lymph node & $1 / 8$ & $1 / 8$ & $1 / 3$ & $6 / 22$ \\
Peyer's patch & $1 / 8$ & $1 / 8$ & $0 / 3$ & $9 / 21$ \\
Faeces & $7 / 7$ & $6 / 7$ & $3 / 3$ & $17 / 19$ \\
\hline
\end{tabular}

ॠNo of rats with positive bacterial culture/ No studied.

in another status A series with a background of $0.409(0.201)$ the incidence of arthritis was $62 \%(5 / 8)$. In line with the background values for yersinia specific antibodies were the serum gammaglobulin levels determined at the beginning of the experiments; the values were $7.5(1.3) \mathrm{g} / 1$ for 22 status A rats and 3.5(1.5) $\mathrm{g} / \mathrm{l}$ for 12 status $B$ rats $(\mathrm{p}<0.001)$.

A difference in the antibody profiles between status A and status B rats was also confirmed at the end of the experiments. About half of status $A$ rats had antibodies against $B$ piliformis, $\mathrm{KRV}$, and Toolan $\mathrm{H}-1$ virus whereas none of the status B rats had any of these antibodies. All animals tested were free of antibodies against $M$ pulmonis (table 5).

\section{Discussion}

At the initial phase of these experiments we suspected that the external environment as such had a decisive effect on the susceptibility to arthritis. This turned out to be wrong, as use of three different environments resulted in similar development of arthritis. Instead, we realised that the preimmune or microbiological status of the rats may have been decisive. We considered it possible that the status A rats were already exposed to yersinia before the experiments. This is suggested by the significantly higher background values of yersinia specific antibodies, particularly of the IgG class antibodies, for status A rats than for status B rats (figure). This suggestion is unlikely for the following reasons: (a) No significant differencies are observed when 14 or 30 day values of yersinia specific IgG class antibodies are compared between between status A and status B rats. (b) No clear correlation between the background values and arthritis incidence could be observed. (c) The total gammaglobulin levels for the status A rats were also significantly (twofold) higher than

Table 5 Serum antibodies against selected rat pathogens at the end of experiment. Tests for antibodies against $\mathrm{M}$ pulmonis were always negative

\begin{tabular}{lllll}
\hline \multirow{5}{*}{$\begin{array}{l}\text { Rat } \\
\text { status }\end{array}$} & Environment & \multicolumn{3}{l}{ Antibodies against } \\
\cline { 3 - 5 } & $\begin{array}{l}\text { Kilham rat } \\
\text { virus }\end{array}$ & $\begin{array}{l}\text { Toolan } H-1 \\
\text { virus }\end{array}$ & $\begin{array}{l}\text { Bacillus } \\
\text { piliformis }\end{array}$ \\
\hline A & I & $6 / 10^{\star}$ & $5 / 9$ & $4 / 9$ \\
B & I & $0 / 5$ & $0 / 5$ & $0 / 5$ \\
B & II & $0 / 3$ & $0 / 3$ & $0 / 3$ \\
B & III & $0 / 5$ & $0 / 5$ & $0 / 5$ \\
\hline
\end{tabular}

${ }^{\star}$ No of animals with antibodies/number tested. respectively; figure). The background levels were not inversely related to the arthritis incidence, in contrast to expected results. For instance, in a status A rat series with a background value of $0.385(0.097)$ the incidence of arthritis was $25 \%$ (1/4), whereas 
those for status $B$ rats. In addition, as the status A rats had a high frequency of antibodies against several rat pathogens (KRV, Toolan $\mathrm{H}-1$ virus, and $B$ piliformis), we regard the background of yersinia specific antibodies as part of a general (polyclonal) immunostimulation. The similar yersinia specific antibody responses on days 14 and 30 in status $A$ and status $B$ rats also exclude immunosuppression, potentially induced by the viral infections, as a cause of decreased arthritis susceptibility. Another potential factor which could have influenced our results is a difference in the genetic make up of the two strains of SHR rats. As the antigenic discrepancy is limited to the blood group antigen RT3, however, this possibility seems extremely unlikely.

We are in favour of the explanation that a preceding exposure of status A rats to certain rat pathogens (and possibly to undefined microbes) is a decisive factor resulting in decreased susceptibility to yersinia associated arthritis. There are previous examples which agree with our present observations. Taurog et al have shown that clinically mild $M$ pulmonis infection delays the onset and reduces the severity of experimental arthritis in rats. ${ }^{9}$ The results were valid for adjuvant arthritis and collagen induced arthritis. Germ free F344 rats are known to develop severe adjuvant induced arthritis, whereas in the same experiments the conventional rats and the specific pathogen free rats developed considerably milder disease. ${ }^{10}$ Likewise, germ free F344 rats treated with $E$ coli developed only mild adjuvant arthritis. ${ }^{11}$ Pretreatment of rats with the mycobacterial 65 kilodalton heat shock protein prevents the subsequent development of adjuvant arthritis, streptococcal cell wall induced arthritis, or pristane induced arthritis. ${ }^{12-14}$ Also, pretreatment with nonapeptides identical or closely related to the 180-188 amino acid sequence of the 65 kilodalton mycobacterial protein has been shown to prevent adjuvant arthritis. ${ }^{15-17}$ In the same fashion, BB rats susceptible to insulin dependent diabetes mellitus become resistant to the disease when infected with particular strains of lymphocyte choriomeningitis virus. ${ }^{18}$

The exact mechanisms by which the host microbial flora, subclinical infection, or pretreatment with heat shock protein affects the disease susceptibility are not completely understood. In the experiments with streptococcal cell wall induced arthritis, van den Broek et $a l^{13}$ proved that in the rats protected against arthritis by pretreatment with heat shock protein, streptococcal cell wall specific $T$ cell responses were suppressed. On the other hand, the pretreatment had no effect on the production of antibodies against streptococcal cell walls, nor on a non-specific inflammatory reaction or on general cellular immunity in vivo. Also, the protection against streptococcal cell wall induced arthritis was transferable using spleen cells. These data indicate that the protection was immunologically specific and mediated by the lymphoid cell population. Accordingly, Winfield has suggested that recognition by $T$ cells of a variable epitope of 65 kilodalton heat shock protein stimulates protective immunity. ${ }^{19}$ In the light of the experience gained with adjuvant arthritis, experimental allergic encephalomyelitis ${ }^{15-17}$ and inhibition of $\mathrm{T}$ cell activation, ${ }^{20}$ the competitive binding of critical peptides by major histocompatibility antigens seems to be the most attractive explanation for the disease inhibition. Our data are in agreement with this view, even though experiments to prove it are not feasible owing to the unknown nature of the protective agents. Also, attempts to clarify the role of different microbes in this respect would require specifically equipped experimental quarters for the animal housing.

The suppression of arthritis development by an altered microbial load of the host or by subclinical infections seems to be a true and reproducible phenomenon, as indicated by the present and previous findings. ${ }^{9-11}$ In addition, we have made a similar observation in Lewis rats using the yersinia associated arthritis as a model (Hill JL and Toivanen $\mathrm{P}$, in preparation). Altogether, this phenomenon explains the failure to induce yersinia associated arthritis in the Lewis rats in our previous studies ${ }^{1}$ and also several other published ${ }^{91121}$ and unpublished observations on variability in susceptibility to arthritis.

We thank Jeri $\mathrm{L}$ Hill, $\mathrm{PhD}$, for valuable help in planning of the experiments and interpretation of the data and Marlene Mikkola for expert technical assistance. This work was supported by Sigrid Jusélius Foundation and Turku University Foundation.

1 Toivanen A, Merilahti-Palo R, Gripenberg C, LahesmaaRantala R, Söderström K-O, Jaakkola U-M. Yersiniaassociated arthritis in the rat: experimental model for human reactive arthritis? Acta Pathol Microbiol Immunol Scand Sect C 1986; 94: 261-9.

2 Hill J L, Yu D T Y. Development of an experimental animal model for reactive arthritis by Yersinia enterocolitica infection. Infect Immun 1987; 55: 721-6.

3 Merilahti-Palo R, Gripenberg-Lerche C, Söderström K-O Toivanen P. Long-term follow-up of SHR rats with experimental yersinia associated arthritis. Ann Rheum Dis 1992; 51: $91-6$.

4 Committee on care and use of SHR rats. Spontaneously hypertensive (SHR) rats; guidelines for breeding, care, and use. Ilar News 1976; 19 (No 3): G1-20.

5 Laird W J, Cavanaugh D C. Correlation of autoagglutination and virulence of Yersiniae. $\mathcal{f}$ Clin Microbiol 1980; 11: 430-2.

6 Koch A L. Growth measurement. In: Gerhardt P, Murray R G E, Costilow R N, et al. eds. Manual on methods for general bacteriology. Washington DC: American Society for Microbiology, 1981: 188-91.

7 Granfors K, Vilianen M K, Toivanen A. Measurement of immunoglobulin $M$, immunoglobulin $G$ and immunoglobulin $M$, immunoglobulin $G_{\text {Yersinia }}^{\text {and }}$ enterocolitica by enzyme-linked immunosorbent assay: conterocolitica by enzyme-linked immunosorbent assay: comparison of lipopolysaccharide and who

8 Jeppsson J-O, Laurell C-B, Franzén B. Agarose gel electrophoresis. Clin Chem 1979; 25: 629-38.

9 Taurog J D, Leary S L, Cremer M A, Mahowald M L, Sandberg G P, Manning P J. Infection with Mycoplasma pulmonis modulates adjuvant- and collagen-induced arthritis in Lewis rats. Arthritis Rheum 1984; 27: 943-6.

10 Kohashi O, Kuwata J, Umehara K, Uemura F, Takahash T, Ozawa A. Susceptibility to adjuvant-induced arthritis among germfree, specific pathogen free and conventional rats. Infect Immun 1979; 26: 791-4.

11 Kohashi O, Kohashi Y, Takahashi T, Ozawa A, Shigematsu N. Suppressive effect of Escherichia coli on adjuvantinduced arthritis in germ-free rats. Arthritis Rheum 1986; 29: 547-53.

12 Billingham M E J, Carney S, Butler R, Colston M J. A mycobacterial $65-\mathrm{kD}$ heat shock protein induces antigenmycific suppression of adjuvant arthritis, but is not itself specific suppression of adjuvant arthritis, but
arthritogenic. $₹$ Exp Med 1990; 171: 339-44.

13 van den Broek $M$, Hogervorst E J M, van Bruggen M C $\mathrm{J}$, van Eden $\mathrm{W}$, van der Zee $\mathrm{R}$, van den Berg $\mathrm{W} \mathbf{B}$. Protection against streptococcal cell wall-induced arthritis Protection against streptococcal cell wall-induced arthritis
by pretreatment with the $65-\mathrm{kD}$ mycobacterial heat shock by pretreatment with the $65-\mathrm{kD}$ mycob
protein. $\mathcal{F}$ Exp Med $1989 ; 170: 449-66$ 
14 Thompson S J, Rook G A W, Brealey R J, van der Zee R, Elson C J. Autoimmune reactions to heat-shock protein in pristane-induced arthritis. Eur $\mathcal{F}$ Immunol 1990; 20: 2479-84

15 van Eden W, Thole J E R, van der Zee R, et al. Cloning of the mycobacterial epitope recognized by $T$ lymphocytes in adjuvant arthritis. Nature 1988; 331: 171-3.

16 Yang X-D, Gasser J, Feige U. Prevention of adjuvant arthritis in rats by a nonapeptide from $65 \mathrm{kD}$ mycobacterial heat-shock protein. Clin Exp Immunol 1990; 81: 189-94

17 Wauben M H M, Boog C J P, van der Zee R, Joosten I, Schlief A, van Eden W. Disease inhibition by major histocompatibility complex binding peptide analogues of disease-associated epitopes: more than blocking alone. $f$ Exp Med 1992; 176: 667-77.

18 Schwimmbeck $P$ L, Dyrberg $T$, Oldstone $M$ B A Abrogation of diabetes in $\mathrm{BB}$ rats by acute virus infection; association of viral-lymphocyte interactions. F Immunol 1988; 10: 3394-3400.

19 Winfield J B. Stress proteins, arthritis, and autoimmunity. Arthritis Rheum 1989; 32: 1497-504.

20 Williams W V, Weiner D B, Borofsky M A, Rubin D H, Yui $\mathrm{K}$, Greene M I. Modulation of T cell responses with MHC-derived peptides. Immunol Res 1992; 11: 11-23.

21 Taurog J D. Studies of the cellular basis of adjuvant arthritis in the rat. Adv Inflamm Res 1984; 7: 161-70.

列 